\title{
Just a question of time? The composition and evolution of immigrants' personal networks in Catalonia
}

\author{
Mireia Bolíbar, Joel Martí and Joan Miquel Verd \\ Centre d'Estudis Sociològics sobre la Vida Quotidiana i el Treball (QUIT) - Institut d'Estudis del Treball (IET) \\ Universitat Autònoma de Barcelona, Spain
}

Published in International Sociology, online before print, 2015.

The published version is available at Sage via

http://dx.doi.org/10.1177/0268580915579925

\begin{abstract}
This article analyses the composition and evolution of migrants' personal networks during their settlement process. Migration studies have emphasized the relational dimension of the migration process, but the topic has rarely been analysed systematically using social network analysis. Based on ego-network analysis and interviews with Ecuadorian and Moroccan immigrants in Catalonia, this article shows the diversity of configurations of migrants' personal networks and their evolution: over the years only some migrants break their ties with the society of origin and substitute them with contacts with locals; others maintain or increase transnational ties; and yet others create co-ethnic ties in the host country. This diversity is explained in the article by examining migrant characteristics and circumstances prior to migration, such as the details of their migration projects and the features of their premigratory contacts. The results show that the interaction of gender with the organization of the migration process seems to have a strong impact on the evolution of these networks. At a methodological level, social network analysis proves to be a fruitful strategy for analysing the diverse incorporation of migrants in the host society.
\end{abstract}

\section{Keywords:}

Personal networks, migration networks, migration project, transnationalism, Catalonia, Spain, Ecuadorean immigrants, Moroccan immigrants.

Corresponding author: Mireia Bolíbar, Centre d'Estudis Sociològics sobre la Vida Quotidiana i el Treball (QUIT) - Institut d'Estudis del Treball (IET), Universitat Autònoma de Barcelona, Campus Universitari, Edifici B, 08193 Cerdanyola del Vallès (Barcelona), Spain.

Email: Mireia.Bolibar@uab.cat 


\section{Introduction}

Although many studies on migration have stressed its relational dimension (among many others, Amit and Riss, 2007; Basch et al., 1994; Hagan, 1998; Pedone, 2010; Portes, 1998; Salaff and Greve, 2013; Vertovec, 2003), the immigrant population has still been little studied from a social network perspective (Lubbers et al., 2010). The present study uses this methodological approach, which has proved fruitful for analysing the characteristics of personal networks, to study the composition and evolution of migrants' personal networks during their settlement process (Lubbers et al., 2010; Lubbers and Molina, 2013; MayaJariego and Armitage, 2007).

This article seeks to identify the degree and form in which new ties are established in the host country, either with autochthonous people or with other immigrants. Transnational approaches have pointed out rightly that migration processes do not necessarily involve a loss of contact with people living in the country of origin and a progressive substitution of these contacts with new relations with residents in the host country. Contrary to what assimilation models claim, transnational approaches contend that there is no clear-cut breaking point between the life "before" and "after" migration. Building on these considerations, this article also seeks to explain the forms, times and bases of transnational networks created between migrants and people from their country of origin. In other words, to identify what elements produce greater transnational connection with the country of origin, and what elements facilitate an evolution of the networks towards greater assimilation.

Many factors are involved in the evolution of pre-migratory and post-migratory personal networks of immigrants. In this article we focus in particular on two factors related to the way in which the migration process is organized: migration networks and the migration project. The aim is not to attribute the composition and evolution of migrants' personal networks only to these two factors, but to see the influence that they may have in these networks. The diversity of situations in which migration can occur (such as varying numbers of previous contacts in the host country and in the country of origin, an individual or family strategy, desire to stay, desire to return or circular migration) suggests that the development of contact networks is also diverse. It is not sufficiently clear, though, under what circumstances prior conditions before migration affect how migrants will develop their networks in the host country.

On a methodological level, we aim to show that social network analysis is a good strategy for operationalizing the theoretical implication of transnationalism as well as of other theoretical explanations (assimilation, multiculturalism and segmented assimilation) in relation to personal networks of immigrants. More specifically, we use in our research a mixed methods design based on a personal network questionnaire and biographical interviews applied to a sample of Ecuadorian and Moroccan immigrants living in Catalonia. This design is used to address the following three research objectives: (1) to analyse the extent to which the composition of personal networks of immigrants changes over the years; (2) to identify the diversity of configurations of personal networks existing among them; and (3) to determine how the initial conditions of migration explain the development of these configurations. 


\section{Migration and social networks}

The concept of migrations as processes involving a break with the society of origin and subsequent acculturation in the host society has been dominant in assimilation theory (Alba and Nee, 1997; Park and Burgess, 1921). Translated into the personal networks of immigrants, this would mean that, in the course of time, interactions in new social environments (workplace, school, etc.) would involve increased contact with persons residing in the host country, while the number of contacts in the country of origin would decrease. Thus, as part of the overall integration process that takes place over the years, the configuration of personal networks of immigrants would look more and more like those of the natives of the host society (Soroka et al., 2007), so the proportion of contacts with autochthonous persons would be very high.

However, many studies indicate that the linear model of assimilation theory is by no means a faithful reflection of the reality of many migration processes, which are characterized, rather, by a diversity of types of migrant adaptation (Chan and Plüss, 2013; Pries, 2001). Some scholars using a multicultural approach have pointed out the recurring strategies of reactive ethnicity adopted by immigrants (Glazer and Moynihan, 1963). Moreover, as Berry (2001) points out, when there is prejudice and discrimination for ethnic reasons, or simply when separation of immigrants is demanded and enforced by the host society, the result is the separation or marginalization of immigrants from the autochthonous population (Berry, 2001: 620). The model of "segmented assimilation" (Portes and Rumbaut, 2001) also suggests the existence of migrant settlement processes other than assimilation into the "white middle class": assimilation as working class and dissonant acculturation both lead to the formation of co-ethnic communities. From the perspective of personal networks, these processes would involve the development of networks of contacts in which the presence of autochthonous persons would be small and co-nationals and other immigrants would form the bulk of the personal network.

The so-called transnational approaches are perhaps the ones that have most strongly questioned the assimilation model, showing the multi-local nature of migration processes. Return to the country of origin or simply circular migration is a possibility considered and in many cases carried out by migrants (Parreñas, 2010; Portes et al., 1999; Waters, 2011). Furthermore, there are people (and especially women) who never end up "leaving" their country of origin, especially if children or part of the immediate family remain there (Hagan, 1998; Krzyżowski and Mucha, 2014; Menjívar, 2006; Pedone, 2010). Whether or not transnationalism is a recent phenomenon and whether all or only some immigrants fit the model are still contentious issues, but a large number of scholars consider that immigrants "live dual lives: speaking two languages, having homes in two countries, and making a living through continuous regular contact across national borders" (Portes et al., 1999: 217). The transnational perspective is therefore useful to highlight the fact that multi-local and nonlinear migration is more common than is assumed by assimilation approaches and that movement in migration processes is not always only one-way (Cohen and Sirkeci, 2011). Applying this perspective to the study of personal networks would involve rejecting the assumption that, over the years, immigrants' contacts will be developed mainly in the host country.

As stated by Guarnizo and Smith (1998) and Gold (2001), studies on transnationalism tend to transmit a vision of transnational networks as a "natural" element proper to the 
globalized world of the 21st century. They stress the remodelling of global time and space, the diasporic identities and the innovation in the forms of cultural hybridization that arise from transnational links (see for instance, Chan and Plüss, 2013). However, the structural elements that lead to the creation of such networks (Gold, 2001) and the family strategies on which they are based (Ho, 2008) have been less studied.

The institutional and structural framework of the host country (immigration policy, labour market characteristics and regional distribution of immigration) and the social positions that people occupy in this framework have an important effect on the possibilities of interaction and therefore the development of the network of contacts of the immigrant population (see, among others, Berry, 2001; Cachón, 2003; Guarnizo and Smith, 1998; Menjívar, 2006; Portes and Rumbaut, 2001; Zhou 1997). Nevertheless, we will focus in this article on the migrant characteristics and circumstances prior to migration, such as the details of their migrant projects and the features of their pre-migratory contacts. These elements have been less taken into account in studying the composition and evolution of migrants' personal networks. By focusing on these elements we want to stress that the way in which the migration process is organized and the resources available previous to the migration have an effect on the later process of settlement and development of the networks of contacts in the host country.

\section{Migration networks and the migration project as explanatory factors for the development of personal networks of immigrants}

As many authors warn (Amit and Riss, 2007; Basch et al., 1994; Chelpi-den Hamer, 2008; Guarnizo and Smith, 1998; Nee and Sanders, 2001), when one is studying the trajectories of immigrants in the host country it makes no sense to set the counter to zero at the time of the arrival of the migrant. If one wishes to identify the factors that may influence the development of personal networks in either direction one must also consider factors prior to the moment of migration. In particular, Nee and Sanders (2001) highlighted in their "forms-of-capital model" the importance of analyzing the individual and family conditions prior to migration and on arrival in order to explain the diversity of immigrant incorporation into the host society. Following this strand, we focus on two aspects that precede migration and are highly related to the family context but go beyond it: migration networks and the migration project.

MacDonald and MacDonald (1964) introduced the concept of chain migration to refer to the process by which new migrants make use of ties with previous migrants to learn about opportunities in the host country and to receive instrumental support for the journey, initial accommodation and employment. This view was further developed by Massey (Massey and Garcia, 1987; Massey et al., 1993: 448-50), who highlights the important role played by migration networks in the migration decision. These "previous" ties between persons living in the host country and potential migrants facilitate the arrival and departure because they also tend to help to fund all or part of the trip, deal with the necessary documentation, or obtain employment and housing (see, among others, Chelpi-den Hamer, 2008; Gaete and Rodríguez, 2010; Pedone, 2010). The "microstructure of migration" (Portes and Rumbaut, 1990, cited in Martínez Veiga, 1997) is thus formed. Specifically, according to Maya-Jariego (2009), the size and organization of the expatriate community determine the opportunity structure for 
establishing new contacts of people who migrate: the personal networks of the pioneers who "open the way" are different from those of later immigrants who join mature, established groups. Thus, depending on the characteristics of the pre-migratory network one could expect differences in the network of contacts once in the host country. While those migrants who do not make use of migration chains will be compelled to make new contacts with natives, those who use them will tend to be incorporated in groups with a large number of relatives and countrymen. For those who join an established group, the migration costs are lower but there is an increased likelihood that social interaction will be limited to an ethnic enclave formed by the support network of co-nationals (De Miguel and Tranmer, 2010; Maya-Jariego, 2009; Parks, 2005: 153-157).

A second, related factor is the migration project, consisting of both the motivation to go to a destination (work, family, politics) and the aspirations and expectations of finally settling there (Izquierdo, 2000; Parella, 2003). As the literature points out, the migration project has an impact on the priorities that guide migrants' economic and social strategies (Hosnedlová and Stanek, 2010). These projects will be carried out differently depending on whether the strategies involve individuals or families (the whole household) and, within the family strategies, on whether they are aimed at providing support to the family group residing in the country of origin, family reunification, or other combinations aimed at providing economic welfare for all members (Parella, 2003; Pedone, 2010). In cases in which the migration project is temporary or circular or in which the person who migrates assumes the economic maintenance of the family in the home country without the aim of reunifying them in the host country, the centrality of the contacts remains in the home country, thus helping to make "reintegration" there more successful (Hagan, 1988; Menjívar, 2006; Parreñas, 2010). On the other hand, migration projects with the aim of reunification and long-term stay in the host country tend to prioritize the establishment of new contacts there (Hosnedlová and Stanek, 2010; Van Meeteren, 2012). Thus, it is likely that migrants whose family remains in the country of origin will have little interest or opportunities (as far as their interactions in the host society could be limited only to the labour market) to build a network of contacts with locals, while those having a project of permanent settlement will possibly have more interest and more environments where to develop contacts with locals, if the family is in the host country with them.

Thus, both the characteristics of the pre-migratory network and the migration project will shape the process leading to the composition of migrants' personal networks: while the former configures the opportunities of access to different types of contacts, the latter defines the centrality of the different relational and geographical spaces and thus the type of contacts that the migrant prioritize. Indeed, we hypothesize that the composition and evolution of these networks will be consistent with assimilation theory only in those cases of classical "one-way migration", while in other less clear-cut and more nuanced processes the transnational perspective is useful for explaining the composition of migrants' personal contacts. These effects have not been empirically tested by means of the personal network perspective and this is the type of analysis we present in the following section. 


\section{Personal networks of Ecuadorian and Moroccan immigrants in Catalonia. Research context and method}

In the first decade of the 21 st century the immigrant population in Catalonia increased significantly, from 4 per cent in 2000 to 17.7 per cent in 2012 (data from the Municipal Population Register, Statistical Institute of Catalonia). Since 2012, this population has been around 1.3 million people, of which about three-quarters were born outside the EU. The context and characteristics of this non-EU migration have been extensively studied (e.g., Aja et al., 2013; Reher et al., 2008; Solé and Parella, 2010). They are mostly of working age and came to Spain for economic reasons, often followed by a process of family reunification. Almost all travelled to Spain as the first destination, and more than half still maintain economic exchanges with the home country through remittances (Reher et al., 2008). Ecuadorians and Moroccans are the two main groups of migrants from outside the EU. They are quite similar in terms of social class; they generally have low qualifications and are employed in the lowest positions of the occupational hierarchy (Miguélez et al. 2011). Nevertheless, they show great cultural, linguistic and religious differences: Ecuadorian's greater language skills in Spanish (although not in Catalan) may help them develop ties with hosts. On the contrary, Moroccan's geographical proximity to their homeland makes circular migration and frequent visits easier and less costly. Together with the similarity on the time zone, which doesn't limit the time available for communication, may enhance their chances for keeping their network in the home country. The analysis presented in this article aims to further the study of these two groups, focusing on the composition and temporal evolution of personal networks.

The research was based on a sequential mixed method research design: first, a quantitative stage identified the personal networks using standardized ego-network questionnaires, and, second, a qualitative stage (designed according to the results of the previous one) enabled the network to be placed in the biographical context of the interviewees. ${ }^{1}$ The fieldwork was conducted in 2010, at the beginning of the economic crisis. Two different instruments of data production were used. First, a questionnaire on personal networks was completed by 153 adults to gather information on the socio-demographic characteristics of ego (the respondent), of 30 alters (adults with whom the respondent had had contact in the past two years by any means), the relationship between ego and alter, the characteristics of the alters (such as their country of birth, current location, or where and when they were met by the interviewee) and the relationships between each pair of alters (from now on, alters will be referred as "contacts"). The sample was stratified regarding the basic structural characteristics of the Catalan population, by gender, age, place of residence and ethnic origin.

Second, biographical interviews were conducted with 18 informants selected from the previous sample according to the structure of their personal network (based on the typology presented in the Results section, which consists of three profiles). The fieldwork was conducted in three towns of Catalonia: Barcelona, Sant Feliu de Llobregat and Balaguer (respectively the capital city, a medium-sized town in the metropolitan area and the small capital of a rural county). The quantitative sample analysed does not differ from the reference population by sex or age, although the population with a higher level of education was somewhat over-represented, especially in the case of the Moroccan population, because of the difficulty of carrying out the questionnaire in Arabic among immigrants with a lower level of 
Table 1. Individuals 18 years old and above born in Morocco and Ecuador and residing in Catalonia, by sex, age and education. Comparison of population and research sample.

\begin{tabular}{lrrrrr}
\hline & \multicolumn{2}{c}{ Population } & & \multicolumn{2}{c}{ Sample } \\
\cline { 2 - 3 } \cline { 5 - 6 } & Morocco & Ecuador & & $\begin{array}{c}\text { Morocco } \\
(\mathrm{N}=77)\end{array}$ & $\begin{array}{c}\text { Ecuador } \\
(\mathrm{N}=76)\end{array}$ \\
\hline Sex & & & & $55.80 \%$ & $50.00 \%$ \\
Male & $59.41 \%$ & $46.97 \%$ & & $54.20 \%$ & $50.00 \%$ \\
Female & $40.59 \%$ & $53.03 \%$ & & $100.00 \%$ & $100.00 \%$ \\
Total & $100.00 \%$ & $100.00 \%$ & & & \\
Age & & & & & \\
$18-34$ & $50.34 \%$ & $48.67 \%$ & & $51.90 \%$ & $50.70 \%$ \\
$35-54$ & $40.99 \%$ & $45.97 \%$ & & $45.50 \%$ & $42.70 \%$ \\
$>54$ & $8.67 \%$ & $5.36 \%$ & & $2.60 \%$ & $6.70 \%$ \\
Total & $100.00 \%$ & $100.00 \%$ & & $100.0 \%$ & $100.0 \%$ \\
Educational level & & & & \\
Primary or lower & $74.40 \%$ & $40.50 \%$ & & $50.60 \%$ & $36.80 \%$ \\
Secondary education & $19.30 \%$ & $47.70 \%$ & & $24.70 \%$ & $50.00 \%$ \\
Higher education & $6.30 \%$ & $11.80 \%$ & & $24.70 \%$ & $13.20 \%$ \\
Total & $100.0 \%$ & $100.0 \%$ & & $100.0 \%$ & $100.0 \%$ \\
\hline
\end{tabular}

Sources: Data on sex and age obtained from the Municipal Population Register, 2010 (Statistical Institute of Catalonia). Educational level obtained from the Immigrants National Survey (Spanish National Statistical Institute), 2007.

education (see Table 1). The mean length of stay of the individuals of the sample was 7.67 years. The sample thus includes migrants who arrived between 2010 and 1987 (with an outlier who arrived in 1973). Coherently with the fact that the immigration flows in Spain arrived mainly in the 2000s, starting in the late 1990s, 90 per cent of the individuals of the sample arrived after 1998.

Although the design was cross-sectional, the time perspective of the evolution of the networks was obtained, first, by calculating how long they had had their contacts and comparing it to how long they had resided in Catalonia and, second, retrospectively through the narratives of the respondents. The analysis was performed in three stages corresponding to the three objectives mentioned in the introduction.

The first stage of the analysis focuses on the evolution of the composition of the networks using the data from the questionnaire, determining whether the composition varies according to the respondents' period of residence in Catalonia. Following Lubbers et al. (2010), in the composition of the network we took into account the origin and residence of the contacts, distinguishing between originals (those who are originally from and live in the respondents' home country), fellows (those from the same country of origin but living in Spain), hosts (those born and living in Spain) and others (those from other origins living in Spain and those living in countries other than the home and host countries). Second, we considered the age of the relationship between ego and each contact, distinguishing between contacts met before ego's arrival in Catalonia, those met in the first three years in Catalonia and those met thereafter. ${ }^{3}$ 
The second stage of the analysis aimed to identify and characterize the diversity of configurations of personal networks. To this end we performed a hierarchical cluster analysis considering the variables of origin, place of residence and place of meeting of the contact, identifying three profiles of personal networks according to their composition.

The third stage focused on identifying the extent to which migration networks and the initial migration project influence the type of network developed by migrants in Catalonia. This stage includes the information from the questionnaires and the semi-structured biographical interviews, which were analysed separately and integrated into the interpretation of the results. The analysis of the cases interviewed allowed us to biographically trace the configuration of the personal networks identified using quantitative methods, to illustrate the results and to contextualize the type of migration processes in which they occur.

\section{Results}

\section{Evolution of the personal networks of migrants: Change or stability?}

To start with, we observed the composition and evolution of the personal networks, considering the type of contacts of which they were composed. Overall, the networks were clearly multi-local and transnational: 29.0 per cent of 4590 contacts identified (30 for each ego) were originals, 39.2 per cent were fellows and 19.7 per cent were hosts (the remainder were contacts from or living in other countries).

The question which then arises is whether this composition varies with the length of stay, i.e., whether over the years there is a progressive reduction of originals and a growing incorporation of hosts in the network. As stated above, though the design was not longitudinal, information on the year in which each contact joined the network allowed us to identify an increase in the proportion of hosts in the personal network in those who have spent more years in Catalonia (Spearman's rho=0.204; $\mathrm{p}=0.01$ ) and a decrease in the proportion of originals (Spearman's rho $=-0.203 ; \mathrm{p}=0.01$ ). However, Figure 1 shows that this process of substitution is slow and that a relevant proportion of originals is maintained even in networks of respondents who have been residing in the host country for a long time, so the development of new contacts in the host country does not result from a break with the home country. ${ }^{2}$

Figure 2 shows the degree of substitution of contacts met in the pre-migration stage with those met in the post-migration stage. The percentage of contacts met before the arrival in Catalonia was 48.5 per cent for the whole sample, decreasing over the period of residence in Catalonia, although the variation is slight and non-significant (Spearman's rho $=-0.120$, $\mathrm{p}=0.14$ ). There was a rapid replacement of the contacts made during the first three years of stay. This finding most likely shows the particular role of initial support played by these first contacts, who later cease to play it (Chelpi-Den Hamer, 2008) and disappear from the network. 


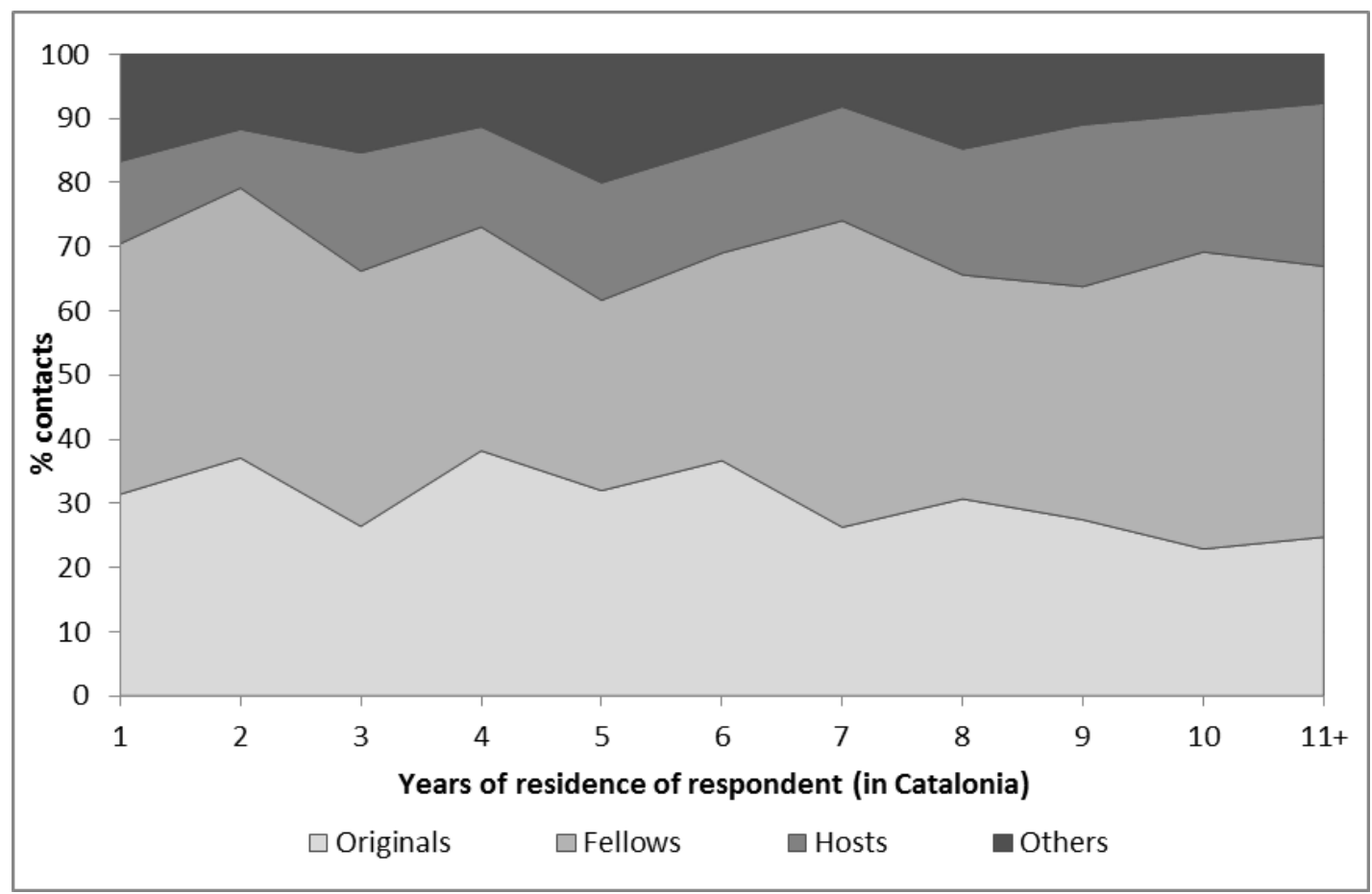

Figure 1. Distribution of types of contacts by years of residence of the respondent in Catalonia ( $\mathrm{N}=153$ egos)

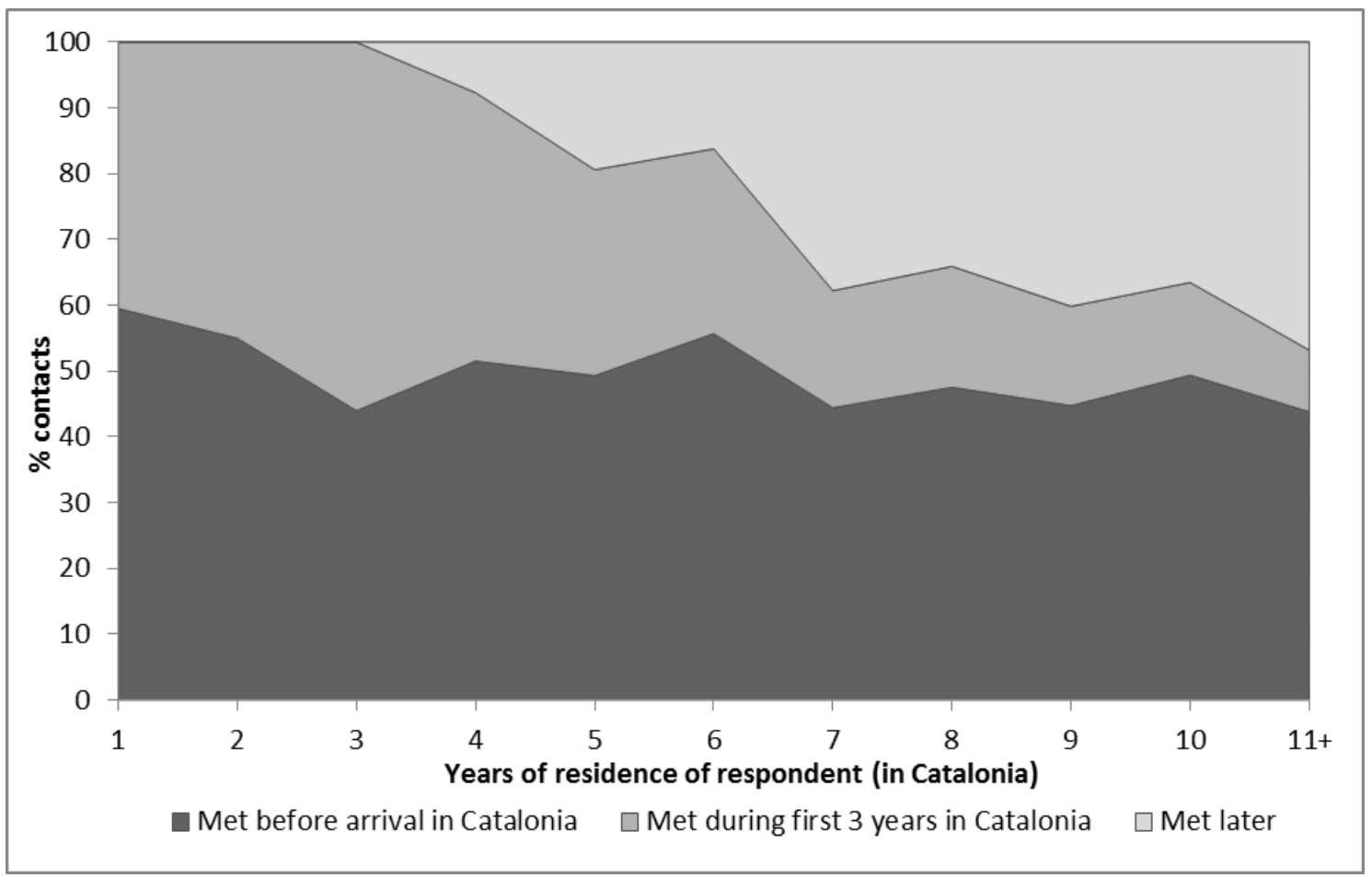

Figure 2. Average distribution of contacts by time of meeting and respondent's year of residence in Catalonia ( $\mathrm{N}=153$ egos)

It can therefore be argued that, despite the overall trend towards assimilation observed in Figure 1, the number of pre-migratory ties tends to persist over time, even in individuals with a long period of residence in Catalonia. As shown in the interviews, the contacts that are 
maintained are family ties and strong friendships, with which the migrants do not lose touch thanks to present-day communication technologies. These results are in line with those of other personal network studies, in which a majority of the closest ties are maintained over time (Molina, 2005).

\section{Diversity of personal networks}

In order to explore the diversity of personal network configurations, we performed a hierarchical cluster analysis of personal networks of respondents with the variables detailed in Table 2. The analysis identifies three types of personal network according to their composition. The first are characterized by a large presence of originals in the network and we have called them dual networks to reflect the dual centrality of the home country and the host country in the networks of contacts of these migrants. The second have a high presence of fellows and a low proportion of originals and hosts, reflecting a relational environment characteristic of the ethnic enclaves described in the literature. Finally, the third are also primarily located in the host country, but with a more heterogeneous ethnic composition, so we have called them mixed networks.

Table 2: Types of personal network by composition of the contacts

\begin{tabular}{lcccccc}
\hline Network type & $\begin{array}{c}\text { Mean } \\
\% \\
\text { hosts }\end{array}$ & $\begin{array}{c}\text { Mean \% of } \\
\text { fellows met } \\
\text { in the home } \\
\text { country } \\
\text { (maintained) }\end{array}$ & $\begin{array}{c}\text { Mean \% of } \\
\text { fellows met } \\
\text { in the host } \\
\text { country } \\
\text { (new) }\end{array}$ & $\begin{array}{c}\text { Mean \% of } \\
\text { contacts from } \\
\text { other origins } \\
\text { living in the } \\
\text { host country }\end{array}$ & $\begin{array}{c}\text { Mean \% of } \\
\text { originals } \\
\text { (contacts in } \\
\text { the home } \\
\text { country) }\end{array}$ & $\begin{array}{c}\text { Mean } \% \\
\text { of } \\
\text { contacts } \\
\text { in other } \\
\text { countries }\end{array}$ \\
\hline Dual (n=55) & 6.55 & 10.30 & 22.91 & 3.76 & 50.61 & 5.88 \\
$\begin{array}{l}\text { Ethnic enclave } \\
(\mathrm{n}=42)\end{array}$ & 13.91 & 22.43 & 39.06 & 12.62 & 8.81 & 3.17 \\
Mixed $(\mathrm{n}=56)$ & 37.08 & 17.50 & 10.89 & 7.14 & 22.98 & 4.40 \\
Total $(\mathrm{N}=153)$ & 19.74 & 16.27 & 22.94 & 7.43 & 29.02 & 4.60 \\
\hline
\end{tabular}

Each of these three network types can be characterized according to sociodemographic variables. The categories associated with dual networks are women, lower levels of education and weaker positions in the occupational structure (with a higher proportion of inactive and unskilled workers). Ethnic enclave networks have a greater presence of immigrants living with an extended family and working in semi-skilled occupations. Finally, mixed networks have a higher proportion of men and wage-earners; they also have a slight tendency to have higher education and work in skilled occupations. In spite of the cultural and geographical differences mentioned, no significant differences between Moroccan and Ecuadorian migrants have been identified in relation to network types.

According to assimilation theory, dual networks could be expected to occur primarily during the early years of settlement and to represent a transition to a mixed profile. However, the results show that although migrants with dual networks have been in Catalonia on average 
for fewer years than the others, three years after the arrival of egos the differences in mean residence time between profiles is no longer significant, and six years after arrival the differences are minimal. In other words, although during the first three years it is more common for immigrants to have a dual network (with more transnational contacts), only in some cases do they evolve towards a mixed network or ethnic enclave network, while in other cases the dual network remains stable over the years.

\section{Migration networks and projects as an explanatory framework of diversity in networks}

As shown by the analyses presented so far, there is no single pattern of evolution of the personal networks of immigrants. Of course, post-migration conditions contribute to reproduce this diversity: i. e., being or not employed affects the possibilities of extending networks beyond the family or neighbourhood level; and the type of occupation exercised leads to differences in the characteristics of the new contacts that are obtained through these jobs (Cachón, 2003; Hagan, 1998; Pajares, 2010; Parella, 2003; Parks, 2005). However, as noted above, we are also interested to see how these different types of network can be related to migration networks and migration projects. To this end, we combined an analysis of the information obtained from the qualitative interviews with the interpretation of graphs representing the type of contacts and the migration stage.

Figure 3 shows the mean values of each type of network, with the average weight of the different types of contacts (originals, fellows and hosts) in the personal network by period in which the contacts were met by ego (before or after ego's arrival in Catalonia) and the average connectivity between them (see Brandes et al., 2008, for more detail on the analytical basis and the computational algorithms used). To better identify the differences between the three networks, we focus on the subsample that has been living in Catalonia more than three years $(n=137){ }^{4}$

As shown in Figure 3a, dual networks have a large number of originals who were met in the pre-migration stage (O1), densely connected to a small number of fellows who were also met in the pre-migration stage (O1-F1). This reflects patterns in which migrants come to Spain with a few contacts who provide them with assistance on arrival and with new contacts with fellows, but they also maintain the majority of the ties in the home country. The centrality of the home country is also observed in the density of the link O1-O2 and F1-O2, which facilitates the establishment of new contacts with originals after migration. In other words, in this profile the transnational contacts not only remain active but are even renewed over time.

As we have seen, women form the majority of immigrants with this type of network. The interviews allow us to add that they are people whose relational environment in the host country is built with weak and volatile ties of low intensity in terms of emotional closeness, exchange of support and frequency of contact. In some cases these are Ecuadorian women who migrate alone, leaving their immediate family in the home country, in order to work in domestic service and send remittances to relatives in the home country. Moroccan women having this type of network, instead, emigrate following their partner, but maintaining close contact with their extended family "left behind". Both tend to express the sentiment that "their people" are located in the home country. 


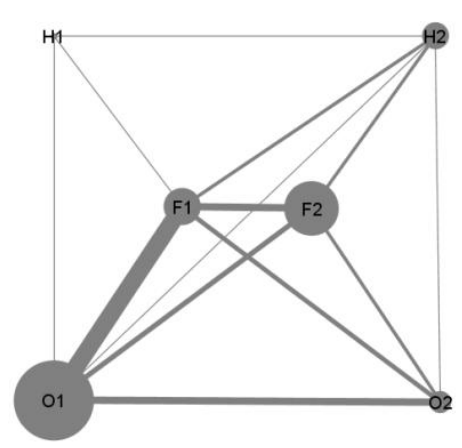

3a. Dual network $(\mathrm{N}=44$ egos $)$

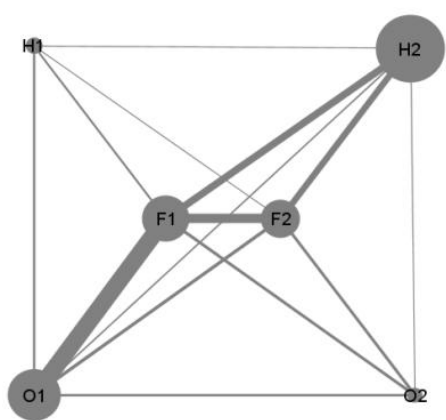

3b. Mixed network $(\mathrm{N}=54$ egos $)$

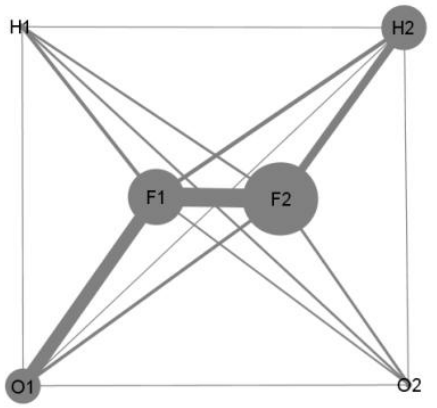

3c. Ethnic enclave $(\mathrm{N}=39$ egos $)$

Figure 3. Clustered graph according to contact type and time of meeting. Comparison by network type.

Hosts who were met before $(\mathrm{H} 1)$ or after $(\mathrm{H} 2)$ ego's arrival in Catalonia; fellows who were met before (F1) or after (F2) ego's arrival in Catalonia; originals who were met before $(\mathrm{O} 1)$ or after $(\mathrm{O} 2)$ ego's arrival in Catalonia. Contacts from other countries or residing in other countries are not shown. The size of the nodes represents the mean volume that each type of contact has in the personal network. The thickness of the connectors represents the average connectivity between the types of contacts. The algorithms for calculating the size of each node and the density of connections between nodes are based on Brandes et al. (2008).

They keep strong instrumental and affective ties with the rest of the family and friends in the home country, who have an emotional centrality in their daily life. In other cases there is a clear desire to return or a project of international mobility to third countries. These situations are reinforced when migrants have a weak position in the labour market (working as a domestic worker within households and/or for long working hours). All of this influences the type of contacts that are maintained and created, thus fostering the maintenance of transnational ties and limiting the opportunity of meeting new people in the host society.

All things considered, this kind of networks show that transnational contacts are not maintained thanks to a privileged position of migrants in the host society, but are the result of a gendered pattern of behaviour and the consequent shortage of relational resources in the host country.

Mixed networks (Figure 3b) are characterized by a high proportion of hosts. The interviews indicate that the combination of a migration project oriented towards long-term stay with a prior network of contacts that facilitate the arrival (and often encourage the migration process) fosters these networks with a greater presence of hosts. Among migrants with mixed networks, hosts were known in some cases even before the arrival in Catalonia (H1), facilitated the journey, provided initial support, and also introduced the newly arrived immigrants into autochthonous circles.

Mixed networks are also produced by having fellows who act as a bridge to meeting new hosts (F1-H2, F2-H2). This finding shows the importance of previous networks of fellows: the contacts prior to migration who produce mixed networks need not necessarily be with hosts because they sometimes arise from the brokerage effect of co-nationals who have a personal network rich in hosts. 
A different context that also favours the formation of a mixed network is one in which settlement occurs in contexts with low immigration, because they came at a time of low emigration to Spain or to areas with a small immigrant population. Interviews show that if migrants then befriend autochthonous people, they tend to maintain those contacts despite the subsequent arrival of other co-nationals.

Finally, ethnic enclave networks (Figure 3c) are characterized by a lower proportion of originals whom the egos had met prior to migration (O1), and by the fact that the core network is composed of fellows living in Catalonia who were met before and after the migration. The density of the link between them (F1-F2) strengthens the network of co-ethnic contacts in Catalonia.

The interviews show that in some cases this means that the pre-migratory contacts that promote or facilitate the migration and provide initial support make a bridge for meeting other fellows who are also immigrants living in the host country and foster immersion in these dense ethnic environments. In this context, family reunification processes are particularly important, both when ego has been the reunifier (mostly Moroccan men and Ecuadorian women) and when ego has been reunified (mostly Ecuadorian men and Moroccan women). Moreover, the low number of originals in the ethnic enclave network can be explained not only by family reunification processes but also sometimes by breaks with the circles in the home country.

\section{Conclusions}

Migration studies have emphasized the relational dimension of the migration process, but have rarely analysed it systematically using social network analysis. This paper shows how personal network analysis offers a methodological framework for empirically testing the relational implications of different theoretical models. First, the study of the composition of personal networks shows the different distribution of autochthonous, co-national and transnational contacts in migrants' communities. Second, dynamic trends during the settlement process can be measured by looking at the moment when new ties were formed. Third, the use of network typologies allows the extant diversity of settlement processes to be identified from a relational approach and the factors leading to them.

The results lead us to conclude that assimilation theories cannot explain the network evolution of all migratory profiles, and that other theoretical models must also be taken into account. The data show that the Ecuadorian and Moroccan population analysed maintain a large proportion of their pre-migratory contacts over the years of residence in the host country without a significant loss of this type of acquaintances in their personal networks. Analysing the composition and evolution of the contact networks of immigrants, we can say, as stated by transnational approaches, that there is no general bipolarity in the configuration of the network between "before" and "after" the emigration.

Quantitative analysis also shows that, for our overall sample, the longer the immigrants have been in the host country, the more ties they will have with the local population and the fewer ties with people who have remained in the home country. These results seem to support the assimilation thesis. However, the cluster analysis allowed us to detect different profiles in the configuration and evolution of immigrants' personal networks, showing that assimilation processes occurred only under certain conditions. Only one of the 
three types identified, the mixed networks' profile, develops in line with the assumptions of the assimilation theory, which expects that over the years contacts with originals will decrease and autochthonous people will be progressively incorporated into the personal networks. However, migrants with this type of network had a greater proportion of contacts with hosts even before migration. Therefore, we cannot say that their contacts with autochthonous people are only the result of progressive integration after their arrival in the host society. This finding calls into question the idea that the incorporation of autochthonous people in the personal network is accompanied by a loss of contacts who were met before the migration. It also shows the importance of pre-migration factors and, specifically, the importance of relational resources prior to migration in the post-migration settlement process.

The other two types of personal network identified, which we have called dual and ethnic enclave networks, show that ethnic, multi-local and transnational personal networks are not exclusively characteristic of the early years of residence in the host country. Rather, under certain circumstances and characteristics of immigrants they are maintained over the years.

The results also confirm that there are elements of continuity in personal networks between the situation before and after migration that play an important role in defining the ensuing evolution of the settlement process. The way in which the migration process is organized, i.e., the specific type of migration networks and projects held, explain the extent of migrant's personal networks in the host society and the conditions under which they evolve.

The pre-migratory conditions are important because they orient the migrants towards one type of relationship or another with their everyday environments in the host country. The migration project galvanises different strategies for the provision of support, which encourages the forging and development of ties in different territories, while also gives meaning to the type of migration networks developed and to the centrality attached to different milieus. In turn, the configuration of migration networks provides specific opportunities for interaction and thus shapes different types of networks' transitivity. To be more specific, considering the three types of network together, we can say that the configuration and evolution of the personal networks of immigrants depends especially on four aspects that are directly related to the migration project and the type of migration network used: the degree of centrality attached to the homeland after the arrival, the balance between work and family life, the family reunification strategy, and the previous networks of fellows. These elements show the need to observe networks and transnational relations as a phenomenon rooted in the constraints and opportunities of specific contexts (Degenne and Forsé, 1999), crossed by different axes of inequality (Gold, 2001; Guarnizo and Smith, 1998). Our findings confirm that since the organisation of the migration processes usually takes place within the framework of the family-household, it is strongly gender-biased. As a consequence, transnational networks are pervaded with the patriarchal norms implicit in how migration plans and chain migration processes are defined, and drive men and women towards developing different types of personal networks.

Moreover, despite the geographical, cultural and linguistic differences between Moroccan and Ecuadorian migrants, it is relevant to note that it is not the origin itself what is associated with one or other pattern of personal networks, but its interaction with gender. The differences by origin that we have observed in the configuration of the networks are above all due to the differences in the sexual division of the organization of emigration within families: Ecuadorian women have employment projects and emigrate as pioneers to a greater extent 
than Moroccan women, which reinforces the reclusion of the latter in the private and domestic sphere and makes them more dependent on the networks of their husbands. In addition, the short distance between Morocco and Spain allows more circular or pendular migration processes that make it easy for family members from the country of origin to join the emigrants. Gender differences are adjusted according to the origin (Parella, 2003; Oso, 2010) because they create variation in the rhythms and dynamics of attraction in migration chains. However, there are not significant differences by nationality in the three types of networks identified: in all cases the family arrangements give women the role of maintaining family ties and they therefore make a greater contribution to the development of dual networks. For Ecuadorian women being in the labour market more than Moroccan women does not make a big difference in terms of contacts, as their employment (many times as domestic workers) does not give them much more opportunities to develop acquaintances with locals.

The aim of this paper was to focus on migration projects and chains and to explore their effects by empirically analysing social networks. From the viewpoint of the composition and evolution of personal networks (and possibly in relation to many other aspects of the settlement process), the results show there is strong continuity between the situations before and after arrival in the host society. However, it should not be forgotten that specific factors of the host society can modify migration projects and trajectories. This could be the case of the changes in the labour market. Our results seem to indicate that factors such as the decrease in job opportunities because of the economic crisis can alter the composition of immigrants' personal networks. As has been seen, the willingness to return or to migrate to other countries also favours the development of transnational contacts, which maximize the information on job opportunities abroad. Future research should examine the changes that occur in the personal networks of immigrants who stay in the host country if their local contacts return to the country of origin or re-migrate.

\section{Acknowledgements}

Joan Miquel Verd thanks professors Aaron Cicourel, David Minkus, Martín Sánchez-Jankowski, Christine Trost and Deborah Lusting for the comments received at the Institute for the Study of Societal Issues (ISSI). We are also grateful for the comments by José Luis Molina, Betina Hollstein and other participants of the International Seminar into Personal Networks held at the Universitat Autònoma de Barcelona in July 2013, as well as for the comments of Antje Roeder and Jan Fuhse.

\section{Funding}

This work was supported by the Spanish Ministry of Science and Innovation under the research grant "Estudio comparado de casos sobre la influencia mutua entre el capital e integración sociales" (CSO2008-01470). The research benefited from the stay by Joan Miquel Verd at the Institute for the Study of Societal Issues (ISSI) of the University of California in Berkeley, funded by the Spanish Ministry of Education, Salvador de Madariaga Programme (PR2011-0521). Mireia Bolíbar was a beneficiary of the FPU programme of the Spanish Ministry of Education. 


\section{Notes}

1. See Bolíbar et al. (2013); Dominguez and Hollstein (2014) or Fuhse and Mützel (2011) for the grounds of mixed methods research in social network analysis.

2. This variable is the difference between the respondents' years of residence in Catalonia and the age of their relationship with each contact. The stage prior to the residence in Catalonia may include countries other than the home country. However, this is not a common situation in the population analysed: according to data from the National Survey of Immigrants by the Spanish National Statistics Institute in 2007, only 4.3 per cent of Ecuadorian immigrants and 6.9 per cent of Moroccan immigrants lived in a third country before arriving in Spain.

3. Moreover, we must also take into account two effects arising from the design that may falsely accentuate the presence of hosts in the personal networks:

1) Selection bias: the presence of hosts in the network was probably lower among those who have left the country and were therefore not interviewed (Reher et al., 2008).

2) The historical context in which the immigration occurs: those who arrived most recently have most likely been supported by migration networks with a higher proportion of fellows.

4. It should be noted that the contacts detected are only those who are currently active. It therefore does not include contacts who may have played an important role in the migration if the contact with them was not maintained.

\section{References}

Aja E, Arango J and Oliver Alonso J (2013) Inmigración y crisis: entre la continuidad y el cambio. Anuario de Inmigración en España. Barcelona: Edicions Bellaterra.

Alba R and Nee V (1997) Rethinking Assimilation Theory for a New Era of Immigration. International Migration Review 31: 826-874.

Amit K and Riss I (2007) The role of social networks in the immigration decision-making process: The case of North American immigration to Israel. Immigrants \& Minorities 25: 290-313.

Basch L, Glick-Schiller N and Szanton Blanc C (1994) Nations unbound: Transnational projects, postcolonial predicaments, and deterritorialized nation-states. New York: Gordon and Breach.

Berry JW (2001) A Psychology of Immigration. Journal of Social Issues 57: 615-631.

Bolíbar M, Martí J and Lozares, C (2013) Aplicaciones de los métodos mixtos al análisis de las redes personales de la población inmigrada. Empiria. Revista de metodología de ciencias sociales 26: 89-116.

Brandes U, Lerner J, Lubbers MJ, McCarty C, Molina JL (2008) Visual Statistics for Collections of Clustered Graphs. IEEE Pacific Visualization Symposium. 47-54.

Cachón L (2003) Discriminación por motivos de origen en el mercado laboral. In: Cruz Roja Española (ed) Empleo e inmigración: Estrategias de comunicación para la promoción de la igualdad de trato. Madrid: Cruz Roja Española.

Chan KB and Plüss C (2013) Modelling Migrant Adaptation: Coping with Social Strain, Assimilation, and Non-integration. International Sociology 28: 47-64. 
Chelpi-Den Hamer M (2008) Migration Patterns and Influence of Support Networks: A Case Study of West Africans in the Netherlands. Gender, Technology and Development 12: 347-364.

Cohen JH and Sirkeci I (2011) Cultures of migration. The Global Nature of Contemporary Mobility. Austin: University of Texas Press.

De Miguel V and Tranmer M (2010) Personal support networks of immigrants to Spain: A multilevel analysis. Social Networks 32: 253-262.

Degenne A and Forsé M (1999) Introducing Social Networks, London: Sage Publications.

Domínguez S and Hollstein B (eds) (2014) Mixed Methods Social Networks Research: Design and Applications. Cambridge: Cambridge University Press.

Fuhse J and Mützel S (2011) Tackling connections, structure, and meaning in networks: quantitative and qualitative methods in sociological network research. Quality \& Quantity 45: 1067-1089.

Gaete R and Rodríguez C (2010) Una aproximación al análisis de las cadenas migratorias en España a partir de la Encuesta Nacional de Inmigrantes. Revista de Ciencia Política 30: 697-721.

Glazer N and Moynihan DP (1963) Beyond the melting pot: the Negroes, Puerto Ricans, Jews, Italians, and Irish of New York City. Cambridge, MA: M.I.T. Press.

Gold SJ (2001) Gender, class, and network: social structure and migration patterns among transnational Israelis. Global Networks 1: 57-78.

Guarnizo LE and Smith MP (1998) The locations of transnationalism. In: Smith MP and Guarnizo LE (eds) Transnationalism from below. New Brunswick: Transaction Publishers, 3-34.

Hagan J (1998) Social Networks, Gender and Immigrant Incorporation: Resources and Constraints. American Sociological Review 63: 55-67.

Ho, EL (2008) "Flexible Citizenship" or Familial Ties that Bind? Singaporean Transmigrants in London, International Migration 46(4): 145-75.

Hosnedlová R and Stanek M (2010) Inmigrantes ucranianos en España. Una aproximación a las pautas de movilidad internacional. Scripta Nova. Revista electrónica de geografía y ciencias sociales Vo. XIV(312). Available at: Available at: http://www.ub.es/geocrit/sn/sn-312.htm

Izquierdo Escribano A (2000) El proyecto migratorio de los indocumentados según género. Papers 60: 225-240.

Krzyżowski $Ł$ and Mucha J (2014) Transnational caregiving in turbulent times: Polish migrants in Iceland and their elderly parents in Poland. International Sociology 29: 22-37.

Lubbers MJ and Molina JL (2013) El proceso de la reconstrucción de la red personal de los inmigrantes: una descripción longitudinal. Empiria: Revista de Metodología de Ciencias sociales 26: 63-88.

Lubbers MJ, Molina JL, Lerner J, Brandes U, Ávila J, McCarty C (2010) Longitudinal analysis of personal networks. The case of Argentinean migrants in Spain. Social Networks 32: 91-104.

MacDonald JS and MacDonald LD (1964) Chain Migration Ethnic Neighborhood Formation and Social Networks. The Milbank Memorial Fund Quarterly 42: 82-97.

Martinez Veiga U (1997) La integración social de los inmigrantes extranjeros en España. Madrid: Editorial Trotta.

Massey DS, Arango J, Hugo G, et al. (1993) Theories of International Migration: A Review and Appraisal. Population and Development Review 19: 431-466.

Massey DS and García España F (1987) The Social Process of International Migration. Science 237: 733-738. 
Maya-Jariego I (2009) Mallas de paisanaje: el entramado de relaciones de los inmigrantes. Redes: Revista hispana para el análisis de redes sociales 17: 273-303.

Maya-Jariego I and Armitage N (2007) Multiple Senses of Community in Migration and Commuting The Interplay between Time, Space and Relations. International Sociology 22: 743-766.

Menjívar C (2006) Liminal Legality: Salvadoran and Guatemalan Immigrants' Lives in the United States. American Journal of Sociology 111: 999-1037.

Miguélez F (coord.), Martín A, Alós-Moner R, Esteban F, López-Roldán P, Molina O, Moreno S (2011) Trayectorias laborales de los inmigrantes en España. Barcelona: Obra Social "La Caixa".

Molina JL (2005) El estudio de las redes personales: contribuciones, métodos y perspectivas. Empiria: Revista de metodología en ciencias sociales 10: 71-106.

Nee V and Sanders J (2001) Understanding the Diversity of Immigrant Incorporation: A Forms-ofCapital Model. Ethnic and Racial Studies 24(3): 386-411.

Oso Casas L (2010) An overview of gender and migration: From the presence of feminised migratory flows to a greater gender balance. Migration Citizenship Education. Available at: migrationeducation.org/fileadmin/uploads/oso_casas_gender__migration_01.pdf (accessed 15 September 2012).

Pajares M (2010) Inmigración y mercado de trabajo. Informe 2010. In: Observatorio Permanente de la Inmigración (ed) Documentos del Observatorio Permanente de la Inmigración. Madrid: Ministerio de Trabajo e Inmigración, 171.

Parella S (2003) Mujer, inmigrante y trabajadora: la triple discriminación. Barcelona: Anthropos.

Park RE and Burgess E (1921) Introduction to the Science of Sociology. Chicago: University of Chicago Press.

Parks V (2005) The geography of immigrant labor markets: space, networks, and gender. New York: LFB Scholarly.

Parreñas RS (2010) Homeward bound: the circular migration of entertainers between Japan and the Philippines. Global Networks 10: 301-323.

Pedone C (2010) Cadenas y redes migratorias: propuesta metodológica para el análisis diacrónicotemporal de los procesos migratorios. Empiria: Revista de Metodología de Ciencias Sociales 19: $101-132$.

Portes A (1998) Social capital: Its origins and applications in modern sociology. Annual Review of Sociology 24: 1-24.

Portes A, Guarnizo LE and Landolt P (1999) The study of transnationalism: pitfalls and promise of an emergent research field. Ethnic and Racial Studies 22: 217-237.

Portes A and Rumbaut RG (2001) Conclusion - The Forging of a New America: Lessons for Theory and Policy. In: Rumbaut RG and Portes A (eds) Ethnicities: Children of Immigrants in America. Berkeley: University of California Press, 301-318.

Pries L (2001) The Disruption of Social and Geographic Space: Mexican-US Migration and the Emergence of Transnational Social Spaces. International Sociology 16: 55-74.

Reher D-S, Cortés L, González F, et al. (2008) Informe Encuesta Nacional de Inmigrantes (ENI2007). Documentos de trabajo. Madrid: INE.

Salaff, J and Greve A (2013) Social Networks and Family Relations in Return Migration, in Chan, KB (ed.) The International Handbook of Chinese Families. New York: Springer, 77-90.

Solé C and Parella S (2010) Non-Communitarian Immigrant Women in the Work Market in Spain. In: 
Irby B, Lara-Alecio R, Calvo-Buezas T, et al. (eds) Immigration in the United States and Spain: Consideration for Educational Leaders. OpenStax CNX. Retreived from: $<\mathrm{http}: / / \mathrm{cnx}$. org/content/col11150/1.1> (1-09-2013)

Soroka SN, Johnston R and Banting K (2007) Ties that Bind: Social Cohesion and Diversity in Canada. In: Banting KG, Courchene T, J and Seidle FL (eds) Belonging? Diversity, Recognition and Shared Citizenship in Canada. Montreal: Institute for Research in Public Policy, 561-600.

Van Meeteren M (2012) Transnational activities and aspirations of irregular migrants in Belgium and the Netherlands. Global Networks 12: 314-332.

Vertovec S (2003) Migration and other modes of transnationalism: towards conceptual crossfertilization. International Migration Review 37: 641-665.

Waters JL (2011) Time and Transnationalism: A Longitudinal Study of Immigration, Endurance and Settlement in Canada. Journal of Ethnic and Migration Studies 37: 1119-1135.

Zhou M (1997) Segmented Assimilation: Issues, Controversies, and Recent Research on the New Second Generation. International Migration Review 31: 975-1008.

\section{Author biographies:}

Mireia Bolíbar is an assistant researcher at the Sociological Research Centre on Everyday Life and Work of the Universitat Autònoma de Barcelona. Her research falls within the areas of social networks, mixed methods, migration, labour trajectories and participation.

Joel Martí is associate professor at the Department of Sociology of the Universitat Autònoma of Barcelona. His research interests include methodological topics such as social network analysis, mixed methods and action research.

Joan Miquel Verd is associate professor at the Department of Sociology of the Universitat Autònoma of Barcelona. His research mainly focuses on the following topics: labour and training trajectories, narrative and biographic analysis, social network analysis and mixed methods 